\title{
Network UTILITIES IN THE U.S. - SECTOR REFORMS Without PRIVATIZATION
}

\author{
INGO VOGELSANG
}

CESIFO WORKING PAPER NO. 1142

CATEGORY 9: INDUSTRIAL ORGANISATION

MARCH 2004

An electronic version of the paper may be downloaded

- from the SSRN website:

- from the CESifo website:

www.SSRN.com

www.CESifo.de 


\title{
NETWORK UTILITIES IN THE U.S. - SECTOR REFORMS WITHOUT PRIVATISATION
}

\begin{abstract}
U.S. network industry reforms led other countries in the past, but have recently run into difficulties in specific areas. In particular, the U.S. telecommunications sector was hit by a deep crisis and electricity reforms suffered under the California disaster. Part of the explanation for these difficulties stems from past successful liberalization and deregulation experiences in other areas suggesting that competition could provide large benefits to hitherto regulated utilities in local telephony and the electricity sector. Part of the explanation lies in an underestimate of the coordination problems, resulting in bad institutional design, and in the difficulty to deal with vested consumer interests.
\end{abstract}

JEL classification: L33, L51, L91.

Keywords: network industries, regulation, competition, telecoms, electricity.

\author{
Ingo Vogelsang \\ Boston University \\ Department of Economics \\ 270 Bay State Road \\ Boston, MA 02215 \\ U.S.A \\ vogelsan@bu.edu
}




\section{Introduction}

While sector reforms in network utility industries in the U.S. were viewed as exemplary and innovative for a long time, the U.S. has lately been viewed as a laggard (Vogelsang, 2003) and confidence in the reform process has been badly shaken in the two main network industries, telecommunications and electricity. Should we change our views of the sector reforms in light of these recent experiences? The current paper successively tries to answer the questions, "What happened here?", "Why did it happen?" and "What can be learned for the future and for countries outside the U.S.?"

The second leitmotif of this paper lies in the semantics of the title. The British economics literature has established a fairly precise use of the word privatization (or rather, privatisation) in the context of the reform of network industries (and otherwise). According to this literature, which is best captured in Armstrong, Cohen and Vickers (1994) and Newbery (2000), the sector reform consists of privatization, liberalization and (de)regulation. Here, privatization means the sale of public enterprises to private shareholders; liberalization means the opening of the markets for competition; regulation and deregulation mean the establishment and reduction of state oversight and of constraints on firms in these industries. In contrast, the U.S. literature takes a very broad view of privatization as anything that increases the scope of markets relative to command and control by governments. This is understandable, since the amount of state ownership in U.S. industries was small to begin with and has changed little under the sector reform 
movement. Thus, the sale of public enterprises does not deserve to monopolize such a valuable and loaded expression as privatization. An analysis of the U.S. privatization in the British sense would therefore shed little light on the corresponding non-U.S. experience. Rather, because privatization in network industries outside the U.S. involves liberalization and (de)regulation as main complementary processes, we concentrate on these aspects of the U.S. experience. ${ }^{1}$ Network industries worldwide have in common that they have gone or are currently going through major reforms. What differentiates U.S. reforms from those of other countries is the lack of privatization in the British sense. Although a sample of one country does not allow for statistical conclusions, the concentration on regulatory and liberalization experiences in the U.S. in comparison with the European experience can help develop conjectures about and extract the independent influence of the ownership change. ${ }^{2}$

I have discussed the meaning of the word privatization because one of my explanations for sector reforms and their success is based on the real effects of words. Economists have, for a long time, recognized the power of brand names as carriers of information as well as of market power. I want to argue that, in the political sphere, there are similar catchwords that one might call political brands or interest group brands. They are not real brands because they lack property rights. However, they similarly provide cheap political information and advantages to those who are naturally identified with them and can build on this information, even if and precisely when it is not fully correct. In my earlier writings, I have implicitly discussed security of energy supply as a justification for the German coal subsidies (for example, in Vogelsang, 1982) and universal service for justifying subsidies and cross subsidies in U.S. telecommunications (for example, in 
Vogelsang, 1998). Today, I want to propose that privatization, deregulation and competition are similar and much more powerful (political or interest group) brands. As the prime example, competition has the full weight of economics since Adam Smith. As an interest group brand competition is naturally identified with the new entrants. Thus, once the feasibility of competition is established in a regulated industry, the new entrants can generate a lot of support from the public, the regulators and antitrust authorities. On the other hand, the incumbent carriers can defend themselves with universal service or carrier of last resort branding.

\section{Examples of Reforms: What Happened?}

\subsection{Introduction}

Network utilities have special properties that make them targets of government interference in the form of public ownership, regulation and antitrust policies. With the exception of mobile telephony, there is often natural monopoly of end-user access, which therefore becomes a bottleneck or essential facility for competitors. There are economies of scope in supply between different infrastructures and services. Sunk costs are most important for access but are by no means negligible elsewhere. Network effects on the demand side include bandwagon effects from network externalities (Rohlfs, 2001, and Faulhaber, 2002). Competition has become feasible due to access and interconnection possibilities and their regulation and through demand growth.

On a time line, attempts for network utility reforms in the U.S. have started in a feeble way already in the 1950s and 1960s, when microwave transmission for long-distance telecommunications started to play a role and equipment suppliers challenged AT\&T's 
absolute monopoly on telephone sets. However, the reforms only received momentum in the 1970s, culminating in the liberalization of the airline industry in 1978 and its subsequent total deregulation. Although the liberalization and deregulation movement for competitive industries (airlines and trucking; to some extent railroads) was different from network utilities, it affected those by setting an example and jump-starting a movement. In contrast to the U.K., the U.S. developed no systematic and comprehensive reform approach to its regulated industries. Deregulation and liberalization in a number of industries could therefore start at the same time that social regulation of health and environmental issues took off and grew in a major way.

Rather than providing a coherent history of network utility restructuring, I will concentrate on a few examples, which reflect my pre-knowledge and biases. They contain successes and failures, where the failures require specific explanations. This holds particularly for failures that produced essentially no winners.

\subsection{Telecommunications}

\subsubsection{General issues}

Telecommunications is the quintessential network industry, in which all users are connected with each other via a network of networks. Coming from a vertically integrated monopoly network, the U.S. has experienced a proliferation of other networks, vertical and horizontal separation of the incumbent AT\&T, the emergence of new types of networks and the beginning convergence of telecommunications with the communications and information industries. The institutional reform of the sector was at the heart of these changes. From the wealth of reform components we only pick the 
deregulation of telecommunications equipment, the liberalization of the long-distance market and the attempts to introduce competition in local telephony. We thereby touch only marginally on mobile telephony, cable TV, the Internet and the reforms in spectrum assignment and spectrum management.

\subsubsection{Deregulation of terminal equipment}

Since AT\&T (Bell) had originally developed the telephone system, it is not surprising that it started out as a vertically integrated company that offered the network services along with equipment manufacture. It is also understandable that this lasted beyond its economic usefulness, as long as AT\&T maintained a virtual monopoly of telephone services. The vertical integration was reemphasized by rate-of-return regulation that could at least be partially circumvented by producing unregulated along with regulated services. However, because AT\&T only offered standardized equipment to its subscribers and since it charged prices well above costs for it, pressure from entrepreneurs arose already in the 1950s and 60s to offer alternative or value added equipment. AT\&T's insistence on network integrity as a defense for its absolute monopoly of equipment dragged out equipment liberalization for about a decade but ultimately was shown to be empty or, at least, easily achievable with less restrictive means, and so equipment was liberalized and totally deregulated by 1980 . AT\&T was already offering equipment through a separate subsidiary (Western Electric) so that full vertical separation of the network monopoly from equipment manufacturing was not decreed until the AT\&T breakup in 1984 (the Modified Final Judgment or MFJ).

Since equipment manufacture is a diverse and potentially competitive industry, the liberalization of the equipment market was an immediate success and has never been 
questioned since. Consumers and other network providers enjoy much more choice and lower prices ever since then. Looking at Lucent, Nortel and other equipment manufacturers today one might, however, get the impression that the liberalization and deregulation of telecommunications equipment was a short-term success and a long-term failure. While this is most probably the wrong conclusion, its mere possibility may prevent us from drawing mistaken conclusions elsewhere (such as for airlines or longdistance telephony).

\subsubsection{Long-distance telephony: Success under vertical separation}

Competition in long-distance telephony can originally be pinpointed to the emergence of microwave technology that confronted AT\&T's cross-subsidized price structure. While microwave transmission was already used during WWII, its competitive impact became first clear, when large telecommunications users wanted to apply it to their companyinternal telecommunications needs. AT\&T was able to prevent this use for about a decade, then its further use for specialized carriers for another decade and, finally its competitive use for the general public for another few years. What has emerged here is a general pattern for incumbents to use the regulatory process to retard change that is against their perceived interest. However, the small victories achieved this way may lead to an ultimately big defeat, in this case the breakup of AT\&T in 1982-84, in which longdistance telephony was separated from the local monopolies.

The MFJ has been the great U.S. experiment with vertical separation of network monopolists. It was deemed necessary, among others, because local telephony was perceived to be a natural monopoly, while long-distance services were viewed as potentially competitive. Since long-distance services need local telephone calls as 
essential inputs, the local monopolies had to be providing bottleneck access to the longdistance companies. This had proved to be contentious and created conflicts of interest and the accusation of monopolization during the 1970s, leading to the U.S. Department of Justice's lawsuit against AT\&T. The breakup occurred by consent decree. ${ }^{3}$ As a result, the court (Judge Greene) was in charge of its execution and acted as a third, very powerful regulator (besides the Federal Telecommunications Commission $[\mathrm{FCC}]$ and the state public utility commissions [PUCs]). From 1984 onwards long-distance telephony developed into an increasingly competitive industry. AT\&T's share in long-distance revenues fell from about $86 \%$ in 1984 to about $42 \%$ in 1998 and simultaneously the HHI among long-distance companies fell from 8,200 to 2,600 (Kaserman and Mayo, 2002, p. 517). Competition was both facilities-based and resale-based. While high local access charges initially kept long-distance charges high, they no longer distorted the competition between other long-distance carriers and AT\&T.

The buildup of excess capacity through several full-sized long-distance networks became obvious already in the 1980s but did not lead to excessive competition, as long as product differentiation and brand names allowed for substantial margins above marginal costs. That episode is by now history and certainly has been replaced by fierce competition today. In 1989 AT\&T was relieved from rate-of-return regulation and came under fairly flexible price caps. 1995 its prices were fully deregulated. The record of long-distance competition received generally favorable reviews from economists (surveyed in Kaserman and Mayo, 2002), but dissenters led by MacAvoy (1996) pointed to evidence that oligopolistic network competition might have led to collusive outcomes by the early 1990s. A major reason for the mixed review is that a large percentage of price reductions 
are explained by steep decreases in access charges that long-distance carriers had to pay local carriers. Thus, while AT\&T's average revenues per minute fell by about $69 \%$ between 1984 and 1998 the average revenues net of access charges fell by only about 44\% (Economides, 2003).

The 1990s brought attempts by the long-distance companies to provide local access services to themselves and local end-user services to others, and the Telecommunications Act of 1996 (the 1996 Act) played to the desire of the large local exchange companies to reintegrate vertically into long-distance services. This begged the question if vertical separation had caused a severe loss of economies of scope. While no concrete evidence has been found, price and productivity trends in U.S. telecommunications are more favorable before than after the 1984 breakup. Thus, Phillips (2002) finds that real prices of telephone services decreased by $1.27 \%$ annually during the $1959-1979$ period, while they only decreased by $0.69 \%$ per year during $1980-2000$. This may indicate that the vertical relationships between separated long-distance and local exchange carriers were associated with high transaction costs. If the rules had been simply biased against either party not both would want to integrate vertically. It is thus not clear if vertical separation gave the U.S. telecommunication sector an advantage over countries with continuing integration of their incumbent dominant firms, such as the UK and the rest of Europe.

The last few years have led to decreasing prices and a deterioration of the profitability of long-distance telephony. The financial outlook of the industry continues to be bleak. In my view, this can be attributed to excess capacity from the fiber optics revolution combined with (a) commoditization of long-distance telephony, (b) mobile substitution and (c) the increasingly successful entry of local exchange companies in the long- 
distance area. Since the networks are sunk, none of these factors is going to disappear soon. Does this mean that long-distance telephony reform has finally become a failure? So far there are no signs that customers will suffer any disadvantages. That could only occur if local exchange companies were able to remonopolize those markets, something that will most likely be prevented by antitrust laws, sunk investments and mobile competition.

Thus, judged at this point, long-distance competition has been a moderate success. However, the general public perception that competition is responsible for the large price reductions experienced over time is only partially true. Competition revealed the large rent transfers that were contained in long-distance access charges and, hence, these were reduced in the political process.

\subsubsection{Local telephony and the 1996 Act}

Like long-distance competition local competition was also triggered by a combination of price distortion and technical innovation. The price distortion came from the universal service policy of subsidizing local telephone subscriptions (on a flat rate basis) through long-distance access charges. Since those access charges originally were a multiple of the long-run incremental costs of access, they invited local access bypass for larger longdistance users. The technological innovation was the optical fiber ring installed by competitive access providers (CAPs). The fiber rings were later copied by incumbent local exchange companies. So, although the CAPs were originally cherry pickers, they helped improve the efficiency of the incumbent networks. 
While CAPs were the forerunners of local competition and while attempts of true local competition started in a few states, such as New York and Illinois in the early 1990s, ${ }^{4}$ it was the 1996 Act that was supposed to jump-start local competition in a big way

- by establishing obligations for local resale with a wholesale discount,

- by providing various unbundled network elements, with which new competitors could construct networks through leasing arrangements at long-run incremental cost,

- by providing for reciprocal interconnection arrangements between competing local networks,

- by making entry of the large local exchange companies dependent on progress in local competition in their territories (Section 271 of the 1996 Act).

In spite of very pro-competitive enforcement by the FCC and most state PUCs, the big push forward did not happen. After over six years since passage of the 1996 Act the new competitors have gained little over $12 \%$ market share in terms of access lines but less than $10 \%$ in terms of revenues (ALTS, 2003). While this looks like a small gain, it is about the same as in the long-distance market over the 1984-1989 period. However, most of local service competitors do not provide their own lines. Over two-thirds of more than 300 competitive local exchange companies operating in 2000 have disappeared by 2003 (ALTS, 2003). Some more promising competitors have gone bankrupt, but may emerge more strongly from Chapter 11 bankruptcy proceedings. ${ }^{5}$ Since most of local competition takes place in the business market and since local residential markets have traditionally been cross subsidized by business services and long-distance services, one can conjecture that prices for business users have declined but official data are missing. 
What explains the slow pace of progress in local competition? Simplest is that local services continue to be priced below costs in many, particularly rural, areas. Second are continuing natural monopoly and bottleneck problems. Third, by making universal service charges explicit, the 1996 Act helped reduce long-distance access charges, thereby eliminating an incentive for backward vertical integration. Fourth, the FCC's enforcement of the 1996 Act was legally challenged and therefore partially in limbo until 2002. At the same time, an extreme unbundling policy was demanded by the FCC. This required organizational and network changes that the local exchange companies could drag out. The local collocation required for loop unbundling is very costly. ${ }^{6}$ All parties underestimated these difficulties. The long-distance carriers underestimated the continuing barriers to entering local markets, even with entry help. And the Bell operating companies underestimated the regulatory hurdles before being able to enter long-distance markets. These hurdles were a direct function of the difficulties of the longdistance carriers to enter the local markets. Universal service policy calls for continuing regulatory interference. Last, continued regulation of end-user prices by state PUCs prevented price rebalancing in accordance with costs. This led to a particular failure for competition to develop for residential users. Thus, the failure to establish local competition quickly is itself a combination of regulatory quagmire and genuine entry barriers in the form of high duplication costs under low penetration.

The future of the FCC's entry help to local competitors is in doubt at this time, as the FCC has been switching from a balanced approach towards service and infrastructure competition to favoring more facilities-based competition. Already, the incumbent local exchange carriers are losing lines to new competitors, to mobile services and to 
broadband Internet. The competitive picture is therefore moving from moderately unsuccessful intramodal local competition to intermodal competition in specific local areas.

\subsubsection{Conclusions on telecommunications}

In all three examples the reform took substantial time from the beginning of the events that triggered them. Meanwhile the incumbent enjoyed continued monopoly power, something that Owen and Braeutigam (1978) ascribe to the U.S. regulatory process in general.

Telecommunications is the major network industry, where technical change played a crucial role in some reforms, but not obviously in all, such as telecommunications equipment (or did it?).

All reforms, however, started from distorted prices that triggered competition. The early success of long-distance competition and delay of local competition are probably both explained by the lack of rebalancing of prices as a result of cost reduction in longdistance services and cost increases in local services. Regulators could therefore potentially have avoided some reforms and accelerated others by pricing more in line with costs. Why did they not? The lack of price rebalancing in telecommunications in the past is intimately connected with the policies of state PUCs, who did not want to raise local service prices, and with the problem of universal service. To some extent, this continues, although the 1996 Act has put universal service on a more rational basis. But, at the same time, universal service policy has expanded and has become highly complicated. 
The U.S. telecommunications sector today provides a bleak picture from the perspective of investors and telecommunications companies. Telecommunications carriers are said to face a debt spiral, and investment advisors have, during all of 2002, advised against the competitive telecommunications segment in a wholesale fashion. The only slightly brighter spot is the monopolistic segment, consisting of incumbent local exchange and cable television companies. From the customer perspective the picture is somewhat different. In the competitive sector customers enjoy low prices and ample choice, while prices in monopolistic markets vary by the regulatory impact. Thus, the economists' conclusions need to be differentiated. Current industry profits or the lack thereof, however, matter for society because they are part of the surplus and because they are important for future investments.

Looking at the reform history over more than 25 years now makes me believe that telecommunications is not an inherently unstable industry but rather that the late 1990s, through the Internet hype, provided for a unique investment optimism that led to excess capacities and financial failures that burden the future for some time. This may, however, reflect on the public view of the working of competition in this sector.

\subsection{Electricity}

\subsubsection{General issues}

In contrast to telecommunications, the U.S. has not been at the forefront of electricity market reforms. Rather, these have been led by the U.K., Chile, Argentina, Norway, Alberta (Canada) and Victoria (Australia). The crucial early academic inputs, however, were American. Joskow and Schmalensee (1983) for the first time systematically 
discussed the vertical economies of the industry, and, starting in the late 1970s, Schweppe proposed real time pricing that has influenced the specific shortrun nodal pricing approach widely used in the U.S. today and proposed by the Federal Energy Regulatory Commission (FERC) as the national standard. ${ }^{7}$

Electricity regulation in the U.S. is, like telecommunications, divided between federal and state regulation. The federal regulator, the FERC, is responsible for interstate high voltage transmission and for wholesale transactions, while the state regulators are in charge of generation, low voltage distribution and intrastate transmission. In practice, there is an overlap of regulatory reach of both. In case of conflicts, the FERC can use federal preemption to solve conflicts in its favor.

\subsubsection{Federal issues}

The Pubic Utility Regulatory Policy Act (PURPA) of 1978 led to independent generation at a time when public utilities had investment problems due to lack of demand growth and nuclear cost overruns and delays. The entrance of small qualified generation facilities (QFs) was also driven by comparatively high prices received from public utilities as stipulated by the law (claimed to be at avoided costs). At the same time, state PUCs disallowed many new (nuclear) power plants built by traditional electric utilities, while other nuclear plants had huge cost overruns and turned out to be unreliable. As a result of the success of QFs and failure of utility investments in generation, state PUCs started to use competitive bidding for new generation rather than simply license the building of new plants by electric utilities (Watkiss and Smith, 1993).

The Energy Policy Act of 1992 (EPact) allowed generation competition beyond QFs, but did not allow for retail wheeling. Rather, it required third party access to transmission 
grids, which formed the basis for FERC orders on open access. Environmental regulation, shorter lead times and new technical developments favored medium-sized gas fired power stations over large coal fired stations, particularly in California.

While restructuring of the electricity industry was largely done by state PUCs, the FERC, until 1999, only provided the conditioning feature of open access transmission. Its 1996 Order 888 on open access required transmission owners to provide access to others "comparable" to themselves (not as strictly as 1996 Act in telecommunications). However, through its 1999 Millenium Order, the FERC directly aimed at restructuring the industry by demanding regional transmission organizations (RTOs) to be formed according to some presepecified criteria. This would require transmission owners either to relinquish their managerial power over their assets or to divest these assets altogether and become shareholders in a specialized vertically separated transmission entity. Most recently, the FERC has embarked on a standardized market design for transmission markets throughout the U.S., but this is still in the rulemaking stage

\subsubsection{State issues: The example of California}

\section{Motivation for California's reforms}

In the early 1990s California had among the highest electricity prices in U.S. The high costs were due to cost overruns with nuclear plants and to long-term fixed price contracts of utilities with small generators. At the same time, the favorable British experience with electricity restructuring seemed to show a way to substantial cost and price reductions. In this situation, California was the first U.S. state to embark on an ambitious electricity sector reform. Rather than learn from the British example, however, the state legislature 
and public utility commission designed something completely new, using ingredients that had never been tried before and putting them together to a complicated whole.

\section{California reform design}

The California reform design contained a complicated set of ingredients:

- An independent system operator (CAISO) was created to solve the complex real-time problems due to nonstorability of electricity and balancing problems in electricity markets (loop flow, voltage and frequency control, reserve requirements etc.). Making the entity independent begs the question of its objectives and incentive structure along with the problematic separation of ownership and control of transmission assets.

- A power exchange (PX) was created for daily trades. The use of the PX was obligatory for main public utilities (until the crisis peaked). The two-tier structure of market organization raised the problem of coordination between CAISO and PX. The CAISO was responsible if trades in the PX would exceed transmission capacity (imbalance market). The CAISO chose a two-zone congestion pricing system instead of nodal pricing that would have incorporated the complexity of actual transmission congestion and revealed the true transmission bottlenecks. In 1999, the PX started to run a forward market, which never really took off because the large utilities feared that long-term contracts would be viewed as imprudent (rather than the opposite!), because it could expose them to high prices if spot prices took a dive and because they could then lose their customers to new entrants, who would price low. ${ }^{8}$

- The main IOUs (investor owned utilities as opposed to municipal electric utilities) had to sell off generation capacity, and they sold virtually all their gas fired plants to 
five companies. ${ }^{9}$ Although these new companies ended up each owning only $6-8 \%$ of the state's generation capacity, they could exercise market power in the day-ahead markets. This possibility of market power of (non-colluding) firms with small market shares in markets with extremely inelastic demands and lumpy supply is a new discovery from these markets. In particular, Borenstein et al. (2002) estimate that market power increased wholesale electricity prices on average by about $33 \%$ in June-October 1998 and by almost 100\% in June-October 2000. In the latter period, this was associated with productive inefficiency of about $\$ 350$ million, which represents about $4 \%$ of electricity expenditure.

- Through the restructuring, the main IOUs had essentially become owners of transmission and distribution capacity that were regulated by open access. Their main business therefore was the sale of electricity to final users. Although there was open entry into this marketing business, the IOUs' end-user prices continued to be regulated. They had to sell under a carrier-of-last resort obligation at a standard offer price, which was $10 \%$ below the pre-restructuring price. This price reduction was financed partially through low-interest bonds that lowered the utilities' cost of capital and partially through a surcharge on customers of incumbents and entrants until the bonds were fully repaid. Since the resulting total charges were, at the time of restructuring, expected to be considerably above the incumbent utilities' costs, the resulting surplus would be used to pay for stranded costs until the stranded costs would be fully paid off or until April 1, 2002, at the latest (Blumstein et al., 2002). As it turned out, entrants could not effectively compete against the standard offer, at which incumbents had to sell to end-users. 
- Time-of-day metering and end-user peak-load pricing in the U.S. is underdeveloped, possibly due to overcapitalization under rate-of-return regulation (the AverchJohnson effect). Demand responses to capacity shortages were therefore minimal, while they could have been achieved through peak-load pricing without an increase in average prices. The lack of demand response enhanced the exercise of market power, which could have been prevented by long-term contracts for electric power in wholesale markets (see Vogelsang, 1987, Allaz and Vila, 1993, and, for experience in the U.K., Newbery, 2000).

To sum up, the California reform design totally concentrated on short-term supply benefits and longer term demand benefits, while neglecting long-term supply issues and short-term demand responses. The naïve expectation was that competitive prices would result at levels well below regulated prices.

\section{Consequences of the California reforms}

The California reforms worked reasonably well for the first two to three years, during which the wholesale price was below the standard offer price plus surcharges. ${ }^{10}$ It nevertheless turned out that downstream competition failed totally as a result of the standard offer by the incumbents, who also benefited from their goodwill and from customer switching costs. In late 1999 and during the course of 2000, adverse issues arose. A severe draught in the Pacific Northwest implied that hydro imports from there had to be cut, resulting in increased generation from gas fired stations, which resulted in increased gas prices and in increased prices for $\mathrm{NO}_{\mathrm{x}}$ pollution permits. Lack of transmission capacity between northern and southern California and between California and eastern states prevented arbitrage opportunities that could have dampened the crisis. 
On top of all that, a strong economy and hot weather implied increased electricity demand.

During and after restructuring, hardly any new generation and transmission capacity came on stream. The lack of new capacity in California is partially the result of the uncertain and protracted restructuring process that new generators wanted to see completed, before committing funds. The PURPA experience in California had shown that electricity supply could be generated outside traditional utilities. However, this usually occurred under long-term contracts. Therefore there existed no empirical basis about how real-time pricing would influence investments (Blumstein et al., 2002). By the end of 2000, the crisis had led to extremely high spot prices, resulting in a liquidity crisis for the two largest IOUs and to their inability to buy all required electricity. In the face of threatened outages and IOU bankruptcies there was an exceedingly slow fix of the problem. Politicians and regulators either believed the crisis would quickly go away or, more probably, they were too timid to respond by adjusting retail prices. The electricity reform had been sold to the public as a way to reduce electricity prices and, therefore, stiff price increases did not fit into the political picture. At the peak of the crisis, in February 2001, Governor Gray Davis was quoted as saying, "If I had wanted to increase prices I could have solved the crisis in twenty minutes." Rather, the crisis lasted for another six months, leading to a number of planned power outages and lost production in other sectors, due to interruptible power contracts.

The crisis ultimately was resolved 
- through an increase in supply with the help of long-term contracts, entered into by the state of California, and through the establishment of solvency through state guarantees and the assumption of state ownership of parts of the transmission system,

- through new generation capacity coming (back) on stream,

- through demand management that provided incentives for lower consumption (general price increases coupled with rebates for reduction of consumption well below previous levels) and

- through a change in the adverse weather conditions and a weakening economy.

Conclusion from the California disaster and beyond

The California problems should not distract the view from some positive aspects of electricity reform experience in the U.S. One main purpose of the reforms was a reduction in generation costs, due to competition. Data indicate that, over the 1981-1999 period partial productivity measures of generation increased in states with competition over states without. For example, plant heat rates fell by $2-2.5 \%$ following vertical separation of ownership. At today's fuel prices that would translate into about $\$ 4$ billion savings per year nationwide (Wolfram, 2003). Whether these and other productivity changes translate into total factor productivity increases and whether they make up for increased transaction costs is an open question.

While California was having its reform meltdown, other U.S. areas, such as New England, New York, and Pennsylvania-New Jersey-Maryland (PJM) were more successful with a more centralized ISO structure designed to recapture lost vertical integration economies (Wilson, 2002). For example, Sutherland (2003) claims that, compared to a sample of non-restructured states, consumers in the five PJM states 
benefited by almost $\$ 3.3$ billion (or almost $15 \%$ of their electricity expenditures) in 2002 alone. Despite the high costs of the crisis to California, the experience therefore suggests that decentralized regulation with a laboratory of the states has worked to some extent. California influenced other U.S. states to restructure but they did not follow the same model. Thus, the response to the California crisis was twofold. States with ongoing reforms strengthened those to avoid California pitfalls. Other states, with the exception of Texas, postponed or canceled any planned electricity reforms at the state level. In addition, the FERC went in to strengthen precautions against the use of short-term monopoly power in generation and to increase interstate transmission coordination and transmission capacity.

Crew and Kleindorfer (2001) see the California electricity crisis as a problem of (a) piecemeal policies, (b) ignorance of experience by others and (c) lack of concern for nuts and bolts.

- An example of piecemeal policies is the lack of coordination between upstream spot pricing and downstream price caps and default service obligation. ${ }^{11}$ Politicians cherish price reductions but even more abhor price increases. This made them neglect the vertical issues. There was a naiveté in the mandated price reductions for residential consumers. The IOUs faced a truncated price distribution with a possible squeeze. If wholesale prices were high IOUs would have to supply at the standard offer price. If wholesale prices were low, they would have to compete with entrants at the spot wholesale price plus other costs.

- The U.K. experience with market power was totally neglected, possibly because of the small market shares of the various generators in California. In the long run, there 
is a major difference between the exercise of market power by withholding existing capacity versus restricting capacity investment. The latter is likely only if entry is restricted (e.g., in transmission).

- Nuts and bolts were neglected in the lack of peak-load pricing and smart metering (a problem for U.S. in general). This was topped by a lack of capacity forecasts, a lack of consideration of low demand elasticities and a lack of hedging. At the very latest, when selling their power plants at unexpectedly high prices, utilities should have expected high prices for generation (Kahn, 2001). Also, economic theory would suggest large effects of forecasting errors in industries with inelastic supply and demand.

In the end, the disaster was the result of a combination of bad design combined with a stretch of unlikely adverse (and partially correlated) events.

\subsubsection{Conclusions on electricity reforms}

What are the main economic benefits of electricity competition? They are potential cost savings and demand responsiveness in generation, a better mix of generating facilities and a reduction in markups for final users. The potential benefits also include faster introduction of new technologies. As long as transmission and distribution are natural monopolies, coordination problems between generation, transmission and distribution are counteracting these benefits. These coordination problems can be solved in the short term through real time nodal pricing, provided no market power is exercised by generators (and transmission entities). Long term investment problems are only partially dealt with so far. If anything, the high expectations from electricity reforms would have to be fulfilled through investment in cheaper capacity. However, the problem that generation 
investment can and will lead to boom and bust cycles (Ford, 2001) is not yet addressed anywhere.

In contrast to telecommunications, where cross-subsidies from long-distance services to local services enabled long-distance competition, there are no apparent cross-subsidy issues in electricity. Rather, price rigidity and pricing below full costs in the past caused stranded costs that are reflected in the difference between the historic costs of an incumbent and the forward-looking costs of an entrant. Under continued monopoly, stranded costs would have little significance beyond intergenerational cross subsidization. However, their very existence was revealed by competitive entry pressure under the then ruling regulated electricity prices.

In contrast to telecommunications, no major technical breakthroughs have occurred in the electricity sector that would explain sector restructuring. Rather, to the extent that technology has played a role, it has been the overestimation of the efficiency of known technologies and the underestimation of their environmental impact that led to a reduction in perceived scale economies in generation. Given the long lead times and long life of power plants, the overestimation led to an overshooting without the possibility to undo the damage. The new situation made competition in generation appear feasible but that did not hold for transmission and distribution, where strong natural monopoly properties persisted. Thus, in order to introduce competition in electricity generation, vertical separation of generation from transmission and distribution and/or open access to transmission and distribution grids was required. 


\subsection{Summary of the experience}

The examples in the telecommunications and electricity industries show some strongly positive experiences in markets that have developed competitively through liberalization and almost total deregulation. The mildly positive examples involve separation of monopoly and liberalized competitive areas with deregulation of the competitive parts. In contrast, the failures include liberalization with heavy-handed asymmetric regulation of incumbents with respect to end-users and open access of incumbent networks to competitors.

Liberalization almost invariably started with entrepreneurs who tried to overcome regulatory entry barriers. Under the multifaceted U.S. regulatory system they were able to get a foot in the door and offer services in some restricted geographic or product space. The success of these niche entrepreneurs provided the basis for cost-of-regulation studies trying to extrapolate the benefits from these niches to the whole industry. Eventually, and with the help of new entrants and customer groups envisaging benefits they were able to convince regulators, courts and legislators about the benefits of liberalization. Opening the door to competition, however, meant that regulation of the incumbent(s) had to be changed as well. This took two main forms. The first and most straightforward was deregulation of the sector, as it occurred for trucking, airlines and telephone equipment. The second was asymmetric regulation of the incumbent, who continued to be regulated at the retail level and incurred new regulation for access to its bottleneck facilities.

Not surprisingly, the successes and failures of reforms in network industries are correlated with the time at which they occurred. As a rule, early reforms, such as airlines, telecommunications equipment and long-distance telephony, have been more successful 
than later reforms, such as electricity and local telephony. This is natural in the sense that the low-hanging fruits are picked first. However, since foreign experience was largely unavailable (or was not used, as in the case of electricity), U.S. regulators and legislators had to learn how to reform these industries. Later reforms could then benefit from these experiences. That seems to have happened only to a limited extent. On the contrary, the consequences derived from the success of earlier reforms seem to have been the belief that the other fruits were also hanging low.

The examples show that markets work as predicted. Compared to regulation, workable competition in airlines, trucking and telecommunications equipment have generated substantial net benefits and allowed for complete deregulation. Vertical separation of the competitive segment has also been successful in efficiency improvements and deregulation of long-distance telephony (roughly between 1984 and 1996). However, the presence of monopoly upstream or downstream and dominant vertically integrated firms have caused problems in local telephony and electric utilities, where rent transfers have been substantial, relative to efficiency gains. All examples have in common that vertical relationships are paramount to successful competition in network utilities.

The longer-lived and sunk the assets employed by incumbents, the more likely it is that reforms reflect attempts to undo past mistakes and are therefore more related to a redistribution of rents from sunk costs than to superior competitive entry. Since long-term contracts are a sunk investment, all these costs were largely sunk and therefore not about to change with liberalization (Borenstein, 2002). 


\section{Some Explanations for reforms and their success}

\subsection{Why did reforms occur?}

While there had been attempts before at reforming regulation and while regulation has perceivably changed over time, the reforms that matter for us all started with some liberalization. It was the pressure of new competitors to be allowed in the market and of customer groups seeing the benefits of such competition that triggered it all. ${ }^{12}$ These benefits were primarily substantial price reductions compared to those under regulation without competition. What differed between the various examples are the reasons for the potential price reductions. In long-distance telephony they were technical and demand changes that lowered costs for entrants and exhibited less economies of scale than the old technologies. This alone would not have sufficed, given that the incumbents' costs were largely sunk. It was the regulatory rigidity of the price structure that made competition feasible. In addition, demand growth reduced sunkness.

Although technology and demand changes provide a convincing explanation for reforms in telecommunications, they are less convincing in trucking, airlines, railroads, natural gas and even electricity. Thus, since commensurate reforms occurred in all these industries, the technical and demand changes can only explain differences (in sequencing, scope and type) between the various industry reforms. In electricity markets the reforms were spurred by a sector crisis, due to cost overruns under rate-of-return regulation, to the rising impact of environmental regulation and to long-term fuel contracts at high prices. Again, that would not have sufficed without the PURPA and the MFJ experience that suggested low costs of vertical separation along with the (largely unsubstantiated) belief that competition in generation would work wonders. 
The liberalization and regulation reforms in the U.S. occurred in a time framework and directionality that suggests a reform movement. It would, however, be very coincidental if similar technology and demand-related reasons occurred in the various industries. It would also be surprising if regulatory snafus would have occurred at about the same time in these cases, some of which had been regulated for almost a century. Rather, it suggests that something contagious happened that was triggered by events in a subset of the industries. This may well have been the technical change in long-distance telephony that showed feasible competition and provided competitive pressure. This - along with airline and trucking deregulation - has worked as eye openers to spread the competitive disease.

\subsection{What explains success or failure?}

The reforms occur first in industries, where claims for expected efficiency increases from deregulation were strongest and most believable (and where there was a group that has a lot to gain). This particularly holds for industries that are naturally competitive (trucking and airlines) or which experience a lot of technical and demand changes (telecommunications). The success in those industries reemphasizes the original claim that is then extrapolated to industries where success is less likely. To the extent that the claims are believed and the results occur with a lag, one might expect overshooting so that reforms occur where they should not or in arrangements that are not viable (California electricity reforms).

The conundrum about the less successful examples is not so much that efficiency gains were absent but rather that the formerly dominant interest groups allowed for large rent transfers at their expense. This is explainable only either by their loss of political power or by a total misjudgment on their part. While the former is plausible, it does not seem to 
be the correct reason. First, the losing incumbents in the unsuccessful reforms did not substantially oppose the reforms as shown by the fact that the California electricity restructuring and the 1996 Telecommunications Act passed essentially unopposed. However, the incumbents only agreed because the reforms were adapted to their perceived needs. ${ }^{13}$ This made the reforms exceedingly complicated and opaque. Second, the Supreme Court has been a protector of regulatory assets under rate-of-return regulation. ${ }^{14}$ So, in my view, the electric utilities and Bell operating companies voluntarily agreed to these reforms, but made a big mistake in doing so.

The same kind of euphoria is expressed in the California (and other) electricity reform as in 1996 Act. Both promised consumers large benefits from competition while shielding them (for example, via guaranteed prices) from the risks (Kahn, 2001). Such euphoria may be necessary to get big reforms started. However, the net efficiency benefits of reforms vary and are not high on average. This implies that care is needed for reforms, and the type I/type II errors have to be assessed in detail, where the problem of evaluation lies in establishing a proper counterfactual.

The two main failures, local telephony and California electricity have in common that retail competition has not been developing, but the reasons are quite different. In case of local telephony, the local loops as remaining bottlenecks hinder competition, even if loops can be rented from the incumbents. In the California electricity market it was the artificially low regulated price for the incumbent's services (although that holds to some extent for local telephony as well). The standard offer, along with natural advantages for large users, seemed to guarantee a Pareto improvement, expressed by unanimity in California legislature, with which electricity reform was passed. As with the U.S. 
Telecommunications Act of 1996, unanimity seems to be a weakness rather than the strength of a piece of legislation because it hints at excessive compromise. The two examples of failures further have in common that the propaganda of reform (the potential entrants) had predicted strong competitive inroads. Such predictions were emphasized by the entrants and not contradicted by the incumbents, leading to a lack of precautions against the effects of forecasting errors.

New entrants have to overcome large hurdles against well-known incumbents with valuable brand names and service reputation. A major problem with the introduction of any retail competition in hitherto monopolistic network industries is that entrants have to overcome switching costs and customer inertia. They therefore need to have either substantially lower costs than the incumbent or face an incumbent's prices that are substantially above his costs. In general in the network industries, the latter seems to be a common phenomenon associated with (often politically motivated) cross subsidization. In that sense, selective competition gets a head start, as long as incumbents do not respond quickly with price restructuring. Such restructuring, however, is often prevented by regulators or not in the interest of incumbents, who fear goodwill losses from the accompanying price increases. The rigidity of past regulatory pricing has led to a crosssubsidization trap, because regulated monopolists need not change politically popular price structures in response to cost changes. While cross-subsidization creates and maintains powerful interest groups backing the status quo, it also plants the seeds for competition in the form of cream skimming. This seed grows particularly strongly if the new technologies lack the strong natural monopoly properties of the new ones, as has happened in long-distance telephony. 
The discrepancy between (current) regulated prices and prices envisaged under competition leads to stranded costs, due to overinvestment or investment in inefficient technology/long-term contracts. The reforms start by concentrating on forward-looking costs of new entrants as compared to full historic costs of incumbents and largely neglect that the forward-looking costs of incumbents (because of large sunk-cost elements) are often even lower. When the reform threat becomes real, the incumbents claim stranded costs from past investment, the recovery of which has often been granted in exchange for their agreement to liberalization. Incumbents have such power because they incurred investments in the stranded assets under a rate-of-return regulated regime that entitled them to the expectation of a fair rate of return on the assets. The expected cost reductions from such liberalization are then attributed to liberalization rather than to bad bookkeeping.

Network utility reforms are shaped by two seemingly opposing forces, competition along with liberalization and regulatory persistence. Once the nose of the camel (competition) is in the tent, the whole camel follows (Hogan, 2001). In contrast, regulators rarely let go. ${ }^{15}$ Full deregulation has only occurred in competitive industries (telephone equipment, trucking and airlines), while in industries with dominant suppliers and natural monopoly characteristics, regulation continues and is influenced by redistributive policies. Those are enhanced by the ability to hide costs and burdens in the regulatory process, while calling it deregulation (Crew and Kleindorfer, 2001). Deregulation and liberalization are separate issues, independent of privatization. Thus, while deregulation may follow the liberalization process, it is not an inevitable and definitely not a short-term outcome. 
Asymmetric regulation is a widespread consequence of sector reforms that have not led to full deregulation. This regulation comes in two forms. First, bottleneck regulation of access to and interconnection with the incumbent's network enhances the feasibility of competition. Second, end-user regulation curbs the incumbent's remaining market power vis-à-vis end-users. Asymmetric regulation, while necessary, creates problems of equity and efficiency. In particular, incentives for investment by incumbents are usually dampened, while investment incentives for entrants can be dampened if bottleneck inputs are provided too cheaply. At the same time, the incentives become excessive in the nonbottleneck areas. Whether this type of regulation has had any influence on the current telecommunications sector crisis with excess capacities in fiber optics is an open question. ${ }^{16}$ In the U.S. the problem with end-user regulation is exacerbated by the fact that it is largely controlled by state PUCs, who want to maintain the traditional patterns of cross subsidies in spite of liberalization. This holds particularly for residential electricity and local telephony. The influence of state regulation is therefore decidedly mixed in accelerating and retarding reform. Acceleration occurs through "progressive" PUCs (with much to gain from competition); delay occurs through lack of uniformity in solving an issue that requires nationwide change (rate rebalancing for Bell system).

Performance-based regulation has increased pricing flexibility in some areas and thereby been conducive to liberalization if only as a concession to make incumbents willing to accept sector reforms. The impact of amending or replacing rate-of-return regulation by incentive regulation (price caps) is somewhat similar to privatization in the British sense. Both increase short-term efficiency incentives. However, both rate-of-return regulation and public enterprises had been a commitment device against expropriation and therefore 
have shielded sunk, lumpy investments (Newbery, 2000). The 1970s and 1980s showed that both devices no longer worked. Rate-of-return regulation prevented innovative investment and was associated with the nuclear cost overruns, while public ownership dried up investments in British Telecom. The further problem with U.S. style rate-ofreturn regulation is that it is not compatible with competition because it reduces the incumbent's cost-reducing incentives and its pricing flexibility. A problem with all regulatory reforms with the exception of full deregulation is that they increase the regulatory uncertainty perceived by a Bayesian investor.

\subsection{Conclusions on explanations}

Reforms have occurred largely because of price rigidities under regulation. Prices became out of line with costs because of political will and because of market changes occurring through innovations, swings in world market prices, new environmental regulation and the like. Since reforms have to overcome the opposition of former beneficiaries, they only occur with a lag. Once successful reforms occur, the former rent transfers are revealed. This makes potential competitors look for similar situations in other industries or industry segments. Reforms then become contagious. The reforms were staggered, because the underlying reasons date at different times. Tipping toward reforms usually occurs, when competitive pressures of actual and potential entrants become sufficiently high. This pressure makes it impossible for incumbents and other beneficiaries of the past to claim that there were no implicit rent transfers.

Reforms fail, because early successful reforms have raised expectations about what competition can achieve. The successful reforms have increased the political value of the brand competition. This leads to the political belief in future reform success and the 
willingness to enter into compromises that win over otherwise losing groups of the reforms. A strong example of this is the standard offer to residential customers in the failed California electricity reform. In the cases of failed reforms the competitive hurdles may be too high to achieve competition, and that combines well with the inability of regulators to let go. It also appears that the failed reform cases did quite badly in their application of performance-based regulation.

\section{Conclusions: The new learning?}

\subsection{Learning for the U.S.}

Only two years ago, a paper on sector reform in U.S. network utilities would have looked differently and would have come to entirely different conclusions. In this assessment I may have become victim of the very cognitive biases that I accuse policy makers of. However, the last two years provide crucial data points for Bayesian updating.

What lessons can be learned from the past U.S. experience in avoiding mistakes and going for successes? Since (with the possible exception of postal services) there are no further network industries to be reformed, the advice can only be directed at improvements in the already reformed industries. By now, it is clear that new reforms will be approached more carefully for some time. In the U.S. electricity industry the restructuring in a number of states has been postponed or scrapped. Those, in which reforms took place, will now have to show long-term benefits before others are going to follow.

Is total deregulation the answer to failed reforms, as some authors like Crandall (1999) suggest? It may well be. The question, however, is "When and where?" Since successful 
reforms have been associated with deregulation, one might be tempted to suggest deregulation as a solution to reform problems or as a way to avoid such problems altogether. Benefits from total deregulation include an obvious simplicity and a lack of mistakes from contradictions in a reform packet. They also potentially include the commitment power of deregulation. However, the short-term irreversibility is also the greatest danger because total deregulation will only work if competition is either sustainable from the beginning or if its emergence over time cannot be prevented by the incumbent (or there are no rents, such as in U.S. railroads). It is obvious that competition worked in the successful reform cases. How can one know that it will work in others? Normatively one could suggest a two-step procedure. If competitive pressure emerges, one should liberalize while simultaneously eliminating regulatory distortions. The problem with this suggestion is the positive issue that regulatory distortions benefit certain groups that would not give them up without fight. Making the implied subsidies explicit is rarely going to help because the benefiting groups would not get the necessary political support, once it is clear that they receive these benefits. Thus, it appears that competition is the necessary discovery process for regulatory distortions as well as efficiency enhancing in its own right.

As the economic theory of regulation has brought out, wealth distribution is more important for understanding economic policies than efficiencies. The proper place for efficiency is to aid distributional policies. While voters behave with reasonable rationality the outcomes can be quite inefficient. Part of this is due to lack of information by all parties and asymmetric information. Competitive pressure exerted on a regulated monopolist reveals otherwise hidden rents that are captured by winning interest groups. 
Once this occurs, the paying groups no longer remain passive and put their political weight against the old regulatory regime. Thus, even though efficiency in the traditional economic sense may not be improved by the resulting reforms, the political efficiency will be.

\subsection{Lessons for other countries}

Many of the network industries in other countries face problems that are similar to those of the U.S. Those foreign industries that have not been reformed yet might learn from the U.S. experience. Since most countries with a comparable institutional, geographic and economic endowment already have reformed their network utilities, they may only be able to learn for future adjustments and reforms of reforms.

In some cases, other countries have done better and therefore have better prospects than the U.S. A California electricity disaster is unlikely to happen anywhere else. The prospects for competition in local telephony are not much brighter elsewhere than in the U.S., but that seems to be the nature of the beast. Generally, European countries seem to have less distorted local telephone charges and less extreme universal service policies than the U.S. (Cherry and Bauer, 2002). This would improve prospects for unbiased competition, although geographic rebalancing is still way off.

One major learning is not to expect Pareto improvements from reform. Rather, there will be winners and losers. This will make reforms that do not benefit the dominating interest groups politically more difficult. In that respect, privatization in the British sense provides an additional instrument because the sale price for the public enterprise can be used to benefit otherwise losing groups. A major problem, however, is that the one-time opportunity of privatization has already occurred in most cases. 
While privatization allows for a clean slate, vertical separation or horizontal divestiture although each would often be beneficial - is difficult to achieve with it. Separation requires enough time, cooperation of management and market values for the firm's assets.

The U.S reform examples and their discussion yielded some answers to our two initial questions about sector crises and political branding. First, the crises should influence our approach to current and future reforms. Second, the political process in the U.S. favors solutions in the name of competition without enough analysis. This could make learning difficult and may lead to swings in the public evaluation of competition if failed reforms give competition a bad name.

\section{References}

Allaz, B. and J.L. Vila (1993), "Cournot Competition, Forward Markets and Efficiency," Journal of Economic Theory 59, pp.1-16.

ALTS (2003), "The State of Local Competition 2003," Association for Local Telecommunications Services, April, available at http://www.alts.org.

Blumstein, Carl, L.S. Friedman and Richard J. Green (2002), "The History of Electricity Restructuring in California," University of California Energy Institute Working Paper CSEM WP 103, August.

Borenstein, Severin (2002), “The Trouble With Electricity Markets and California's Electricity Restructuring Disaster," Journal of Economic Perspectives 16(1), Winter, pp. 191-211. 
Borenstein, Severin, James B. Bushnell, and Frank A. Wolak (2002), "Measuring Market Inefficiencies in California's Restructured Wholesale Electricity Market," American Economic Review 92(5), December, pp.1376-1405.

Bortolloti, Bernardo, Juliet D'Souza, Marcella Fantini, and William L. Megginson (2002), "Privatization and the sources of performance improvement in the global telecommunications industry", Telecommunications Policy 26, pp. 243-268.

Cherry, Barbara A. and Johannes M. Bauer (2002), "Institutional arrangements and price rebalancing: empirical evidence from the United States and Europe," Information Economics and Policy 14, pp. 495-517.

Crandall, Robert W. (1999), "Managed Competition in U.S. Telecommunications," Working Paper No. 99-1, AEI-Brookings Joint Center for Regulatory Studies, Washington, D.C., March.

Crew, Michael A. and Paul Kleindorfer (2001), "Regulatory Economics: Twenty Years of Progress?" Journal of Regulatory Economics 21(1), pp. 5-22.

Economides, Nicholas (2003), “Telecommunications Regulation: An Introduction,” Stern School of Business, New York University, available from SSRN Electronic Paper Collection: http://papers.ssrn.com/paper.taf?abstract_id=465020.

Faulhaber, Gerald (2002), "Bottlenecks and Bandwagons: Access Policy in the New Telecommunications," forthcoming in Martin E. Cave, Sumit K. Majumdar and Ingo Vogelsang (eds.), Handbook of Telecommunications Economics, Volume 2, Amsterdam etc.: North Holland/Elsevier. 
Ford, Andrew (2001), "Waiting for the Boom: A Simulation Study of Power Plant Construction in California," mimeo, Program in Environmental Science and Regional Planning, Washington State University.

Hausman, Jerry A. and J. Gregory Sidak (forthcoming), "The Breakdown in the Telecommunications Industry Under Deregulation: The Failure of Good Intentions", Cambridge, UK: Cambridge University Press.

Hogan, William W. (1992), "Contract Networks for Electric Power Transmission," Journal of Regulatory Economics 4, pp. 211-242.

Hogan, William W. (2001), "Electricity Restructuring: Reform of Reforms", Journal of Regulatory Economics 21(1), pp. 103-132.

Isaac, Mark R. (1991), "Price Cap Regulation: A Case Study of Some Pitfalls of Implementation," Journal of Regulatory Economics 3, pp. 193-210.

Kahn, Alfred E. (2001), “The Deregulation Tar Baby: The Precarious Balance Between Regulation and Deregulation, 1970-2000 and Henceforward," Journal of Regulatory Economics 21(1), pp. 35-56.

Kaserman, David L. and John W. Mayo (2002), "Competition in the Long Distance Market," in Martin E. Cave, Sumit K. Majumdar and Ingo Vogelsang (eds.), Handbook of Telecommunications Economics, Amsterdam etc.: North Holland/Elsevier, pp. 509561.

Levy, Brian and Pablo T. Spiller (eds.) (1996), Regulation, Institutions and Commitment: Comparative Studies of Telecommunications, Cambridge: Cambridge University Press. 
MacAvoy, Paul (1996), The Failure of Antitrust and Regulation to Establish Competition in Long-distance Telephone Services, Cambridge, Mass., London, and Washington, D.C.: MIT Press and AEI Press.

McKie, James W. (1970), "Regulation and Free Markets: The Problem of Boundaries," Bell Journal of Economics and Management Science 1, pp.6-26.

Newbery, David M. (2000), Privatization, Restructuring, and Regulation of Network Industries, Cambridge, Mass., and London: MIT Press.

Owen, Bruce M. and Ronald Braeutigam (1978), The Regulation Game: Strategic Use of the Administrative Process, Cambridge, Mass.: Ballinger.

Phillips, Almarin (2002), "What It Was Like, What Happened, and What It's Like Now:

Developments in Telecommunications Over Recent Decades," Journal of Regulatory Economics 21(1), pp. 57-78.

Rohlfs, Jeffrey (2001), Bandwagon Effects in High-Technology Industries, Cambridge, MA: MIT Press.

Schweppe, Fred, Michael Caramanis, Richard Tabors, and Robert Bohn (1988), Spot Pricing of Electricity, New York: Kluwer.

Sidak, J. Gregory and Daniel F. Spulber (1997), Deregulatory Takings and the Regulatory Contract: The Competitive Transformation of Network Industries in the United States, Cambridge University Press.

Sutherland, Roy (2003), "Estimating the Benefits of Restructuring Electricity Markets: An Application to the PJM Region," Center for the Advancement of Energy Markets, September, Available at http://www.caem.org. 
Vogelsang, Ingo (1982), Anreizmechanismen zur Regulierung der Elektrizitätswirtschaft

- Eine Fallstudie zur ökonomischen Theorie der Institutionen, Tübingen: J.C.B. Mohr (Paul Siebeck).

Vogelsang, Ingo (1987), "The Role of Contracts in International Coal Trade", in D. Wood (ed.), The Changing World Energy Economy, Papers and Proceedings of the Eighth Annual North American Conference of the International Association of Energy Economists, M.I.T., November 19-21, 1986, May 1987, pp. 264-269.

Vogelsang, Ingo (1998), "Costing and Pricing of Interconnection Charges in the US: Lessons for Germany?" in Telecommunications Reform in Germany: Lessons and Priorities, Conference Report, American Institute for Contemporary German Studies, pp.74-101.

Vogelsang, Ingo (2002), "Cross-Fertilization Between the U.S. and European Telecommunications Regulation," ifo Studien 48(1), pp. 5-21.

Vogelsang, Ingo (2003), "The German Telecommunications Reform - Where did it Come from, Where is it, and Where is it Going?" Perspektiven der Wirtschaftspolitik 4(3), September 2003, pp. 313-340.

Vogelsang, Ingo and Bridger M. Mitchell (1997), Telecommunications Competition: The Last 10 Miles, Cambridge, Mass., London, and Washington, D.C.: MIT Press and AEI Press.

Watkiss, Jeffrey D. and Douglas W. Smith (1993), “The Energy Policy Act of 1993 - A Watershed for Competition in the Wholesale Power Market," Yale Journal on Regulation 10, pp. 447-492. 
Wilson, Robert (2002), “Architecture of Power Markets," Econometrica 70(4). pp. 12991340.

Wolfram, Catherine (2003), "How Might Restructuring Affect the Efficiency of Electricity Generation in the U.S.?" University of California Energy Institute, Berkeley, CSEM WP 111, April.

${ }^{1}$ Some sale of public enterprises has occurred in the U.S. railroad industry (Conrail, which had been nationalized in the early 1970s to save it from the Penn Central bankruptcy) and some municipal electric utilities but some public enterprises have also spread, when municipal utilities moved into telecommunications.

${ }^{2}$ Bortollotti et al. (2002) provide evidence that regulatory changes are more important than ownership changes in explaining performance of restructured telecommunications sectors.

${ }^{3}$ The other main basis for the suit was the vertical problem of equipment manufacturing. The name Modified Final Judgment resulted, because it legally was drawn up as a modification of AT\&T's 1956 consent decree.

${ }^{4}$ For the history of this local competition see Vogelsang and Mitchell (1997).

${ }^{5}$ As done in official statistics, we treat broadband access as separate from local telecommunications. Broadband access is characterized by inter-modal competition, with cable TV companies having over $60 \%$ of the market and incumbent local exchange companies about $30 \%$, competitive local exchange companies about $3 \%$ and satellite TV the rest. 
${ }^{6}$ Collocation means that competitors can locate their own equipment in the switching offices of the incumbent and thereby interconnect more directly, for example, before a call reaches the incumbent's switch.

${ }^{7}$ This work culminated in Schweppe et al. (1988).

${ }^{8}$ This adverse selection problem of hit-and-run entry is worth further study. It can be resolved by back-to-back contracts so that end-users interested in stable prices would have to commit to long-term contracts as a condition for load-serving entities to sign long-term contracts with generators.

${ }^{9}$ Vertical separation provides market estimates for stranded costs (Kahn, 2001).

${ }^{10}$ In fact, San Diego Gas and Electric, the smallest of the three main IOUs managed to pay back its stranded costs in time to escape the standard offer price in 2000 only to find out that its severe price increases were revoked by the California regulators.

${ }^{11}$ This ignores earlier bad U.S experience with price moratoria analyzed in Isaac (1991).

${ }^{12}$ The breakup of AT\&T was additionally triggered by its desire to get into other markets, such as the computer business (in which it failed miserably).

${ }^{13}$ Barbara Cherry (in personal communication) stated that interest groups concentrate on their perceived most important items of a reform and neglect others that may turn out to be important.

${ }^{14}$ Sidak and Spulber (1997) question this under the heading of "deregulatory takings."

${ }^{15}$ This is the tar baby effect claimed by Kahn (2001). It is based on McKie (1970) and, to some extent, on Owen and Braeutigam (1978).

${ }^{16}$ Favoring this view are Hausman and Sidak (forthcoming). 


\section{CESifo Working Paper Series}

(for full list see www.cesifo.de)

1073 Robert S. Chirinko and Julie Ann Elston, Finance, Control, and Profitability: The Influence of German Banks, November 2003

1074 Wolfgang Eggert and Martin Kolmar, The Taxation of Financial Capital under Asymmetric Information and the Tax-Competition Paradox, November 2003

1075 Amihai Glazer, Vesa Kanniainen, and Panu Poutvaara, Income Taxes, Property Values, and Migration, November 2003

1076 Jonas Agell, Why are Small Firms Different? Managers' Views, November 2003

1077 Rafael Lalive, Social Interactions in Unemployment, November 2003

1078 Jean Pisani-Ferry, The Surprising French Employment Performance: What Lessons?, November 2003

1079 Josef Falkinger, Attention, Economies, November 2003

1080 Andreas Haufler and Michael Pflüger, Market Structure and the Taxation of International Trade, November 2003

1081 Jonas Agell and Helge Bennmarker, Endogenous Wage Rigidity, November 2003

1082 Fwu-Ranq Chang, On the Elasticities of Harvesting Rules, November 2003

1083 Lars P. Feld and Gebhard Kirchgässner, The Role of Direct Democracy in the European Union, November 2003

1084 Helge Berger, Jakob de Haan and Robert Inklaar, Restructuring the ECB, November 2003

1085 Lorenzo Forni and Raffaela Giordano, Employment in the Public Sector, November 2003

1086 Ann-Sofie Kolm and Birthe Larsen, Wages, Unemployment, and the Underground Economy, November 2003

1087 Lars P. Feld, Gebhard Kirchgässner, and Christoph A. Schaltegger, Decentralized Taxation and the Size of Government: Evidence from Swiss State and Local Governments, November 2003

1088 Arno Riedl and Frans van Winden, Input Versus Output Taxation in an Experimental International Economy, November 2003 
1089 Nikolas Müller-Plantenberg, Japan’s Imbalance of Payments, November 2003

1090 Jan K. Brueckner, Transport Subsidies, System Choice, and Urban Sprawl, November 2003

1091 Herwig Immervoll and Cathal O'Donoghue, Employment Transitions in 13 European Countries. Levels, Distributions and Determining Factors of Net Replacement Rates, November 2003

1092 Nabil I. Al-Najjar, Luca Anderlini \& Leonardo Felli, Undescribable Events, November 2003

1093 Jakob de Haan, Helge Berger and David-Jan Jansen, The End of the Stability and Growth Pact?, December 2003

1094 Christian Keuschnigg and Soren Bo Nielsen, Taxes and Venture Capital Support, December 2003

1095 Josse Delfgaauw and Robert Dur, From Public Monopsony to Competitive Market. More Efficiency but Higher Prices, December 2003

1096 Clemens Fuest and Thomas Hemmelgarn, Corporate Tax Policy, Foreign Firm Ownership and Thin Capitalization, December 2003

1097 Laszlo Goerke, Tax Progressivity and Tax Evasion, December 2003

1098 Luis H. B. Braido, Insurance and Incentives in Sharecropping, December 2003

1099 Josse Delfgaauw and Robert Dur, Signaling and Screening of Workers' Motivation, December 2003

1100 Ilko Naaborg,, Bert Scholtens, Jakob de Haan, Hanneke Bol and Ralph de Haas, How Important are Foreign Banks in the Financial Development of European Transition Countries?, December 2003

1101 Lawrence M. Kahn, Sports League Expansion and Economic Efficiency: Monopoly Can Enhance Consumer Welfare, December 2003

1102 Laszlo Goerke and Wolfgang Eggert, Fiscal Policy, Economic Integration and Unemployment, December 2003

1103 Nzinga Broussard, Ralph Chami and Gregory D. Hess, (Why) Do Self-Employed Parents Have More Children?, December 2003

1104 Christian Schultz, Information, Polarization and Delegation in Democracy, December 2003

1105 Daniel Haile, Abdolkarim Sadrieh and Harrie A. A. Verbon, Self-Serving Dictators and Economic Growth, December 2003

1106 Panu Poutvaara and Tuomas Takalo, Candidate Quality, December 2003 
1107 Peter Friedrich, Joanna Gwiazda and Chang Woon Nam, Development of Local Public Finance in Europe, December 2003

1108 Silke Uebelmesser, Harmonisation of Old-Age Security Within the European Union, December 2003

1109 Stephen Nickell, Employment and Taxes, December 2003

1110 Stephan Sauer and Jan-Egbert Sturm, Using Taylor Rules to Understand ECB Monetary Policy, December 2003

1111 Sascha O. Becker and Mathias Hoffmann, Intra-and International Risk-Sharing in the Short Run and the Long Run, December 2003

1112 George W. Evans and Seppo Honkapohja, The E-Correspondence Principle, January 2004

1113 Volker Nitsch, Have a Break, Have a ... National Currency: When Do Monetary Unions Fall Apart?, January 2004

1114 Panu Poutvaara, Educating Europe, January 2004

1115 Torsten Persson, Gerard Roland, and Guido Tabellini, How Do Electoral Rules Shape Party Structures, Government Coalitions, and Economic Policies? January 2004

1116 Florian Baumann, Volker Meier, and Martin Werding, Transferable Ageing Provisions in Individual Health Insurance Contracts, January 2004

1117 Gianmarco I.P. Ottaviano and Giovanni Peri, The Economic Value of Cultural Diversity: Evidence from US Cities, January 2004

1118 Thorvaldur Gylfason, Monetary and Fiscal Management, Finance, and Growth, January 2004

1119 Hans Degryse and Steven Ongena, The Impact of Competition on Bank Orientation and Specialization, January 2004

1120 Piotr Wdowinski, Determinants of Country Beta Risk in Poland, January 2004

1121 Margarita Katsimi and Thomas Moutos, Inequality and Redistribution via the Public Provision of Private Goods, January 2004

1122 Martin Peitz and Patrick Waelbroeck, The Effect of Internet Piracy on CD Sales: CrossSection Evidence, January 2004

1123 Ansgar Belke and Friedrich Schneider, Privatization in Austria: Some Theoretical Reasons and First Results About the Privatization Proceeds, January 2004

1124 Chang Woon Nam and Doina Maria Radulescu, Does Debt Maturity Matter for Investment Decisions?, February 2004 
1125 Tomer Blumkin and Efraim Sadka, Minimum Wage with Optimal Income Taxation, February 2004

1126 David Parker, The UK's Privatisation Experiment: The Passage of Time Permits a Sober Assessment, February 2004

1127 Henrik Christoffersen and Martin Paldam, Privatization in Denmark, 1980-2002, February 2004

1128 Gregory S. Amacher, Erkki Koskela and Markku Ollikainen, Deforestation, Production Intensity and Land Use under Insecure Property Rights, February 2004

1129 Yin-Wong Cheung, Javier Gardeazabal, and Jesús Vázquez, Exchange Rate Dynamics: Where is the Saddle Path?, February 2004

1130 Alberto Alesina and Guido Tabellini, Bureaucrats or Politicians?, February 2004

1131 Gregory S. Amacher, Erkki Koskela, and Markku Ollikainen, Socially Optimal Royalty Design and Illegal Logging under Alternative Penalty Schemes, February 2004

1132 David M. Newbery, Privatising Network Industries, February 2004

1133 Charles Yuji Horioka, The Stagnation of Household Consumption in Japan, February 2004

1134 Eiji Fujii, Exchange Rate Pass-Through in the Deflationary Japan: How Effective is the Yen's Depreciation for Fighting Deflation?, February 2004

1135 Mark M. Spiegel and Nobuyoshi Yamori, Determinants of Voluntary Bank Disclosure: Evidence from Japanese Shinkin Banks, Febrary 2004

1136 Robert Dekle and Kenneth Kletzer, Deposit Insurance, Regulatory Forbearance and Economic Growth: Implications for the Japanese Banking Crisis, February 2004

1137 Takatoshi Ito and Kimie Harada, Bank Fragility in Japan, 1995-2003, February 2004

1138 Kunio Okina and Shigenori Shiratsuka, Policy Duration Effect under Zero Interest Rates: An Application of Wavelet Analysis, February 2004

1139 Francine D. Blau and Lawrence M. Kahn, Do Cognitive Test Scores Explain Higher U.S. Wage Inequality?, February 2004

1140 Michael Rauscher, Economic Growth and Tax-Competing Leviathans, February 2004

1141 Ernst Fehr and Jean-Robert Tyran, Money Illusion and Coordination Failure, February 2004

1142 Ingo Vogelsang, Network Utilities in the U.S. - Sector Reforms without Privatization, March 2004 